W. Yoder, Jr. Ames, Iowa State University Press. pp 471-484

KOUWENHOVEN, B., DAVELAAR, F. G., BURGER, A. G. \& LUTTICKEN, D. (1983) Significance of variant infectious bronchitis serotypes in The Netherlands. Proceedings of the 66th meeting of the Australian Poultry Association. August 31 to September 2, 1983. pp 53-71

KUSTERS, J. G., NIESTERS, H. G. M., BLEUMINK-PLUYM, N. M. C., DAVELAAR, F. G., HORZINEK, M. C. \& VAN DER ZEIJST, B. A. M. (1987) Molecular epidemiology of infectious bronchitis virus in The Netherlands. Journal of General Virology 68, 343-352

MARCHI, R. \& ZANELLA, A. (1984) Avian infectious bronchitis. Investigation of a new serotype and its spreading. Clinica Veterinaria 107 121-125

PICAULT, J. P., DROUIN, P., LAMANDE, J., ALLEC, C., TOUX, J.Y., LE COQ, H., GUITTET, M. \& BENNEJCAN, G. (1995) L'épizootie récente de Bronchite infectieuse aviarie en France: importance, évolution et étiology. Journées de la Recherche Avicole, Mars 1995, 177-178

REED, L. J. \& MUENCH, H. (1938) A simple method of estimating fifty percent endpoint. American Journal of Hygiene 27, 493-497

RINALDI, A., CRESPI, A., CERVIO, G. \& MANDELLI, G. (1966) Isolamento di un ceppo nefropatogeno del virus della bronchite infettiva del pollo. Selezione Veterinaria 7, 284-287

WANG, L., JUNKER, D. \& COLLISON, E. W. (1993) Evidence of natural ricombination within the $\mathrm{S} 1$ gene of infectious bronchitis virus. Virology 192 , 710-716

ZANELLA, A. (1977) Bronchite infettiva nei polli da carne con particolare riferimento alle forme di nefrite-nefrosi. Clinica Veterinaria 100, 407-415

ZANELLA, A., GUALLINI, L. \& MORINI, M. T. (1967) Caratteristiche dei ceppi nefropatogeni del virus della bronchite infettiva aviare. Proceedings of the Società Italianna delle Scienze Veterinarie 21, 895-899

ZANELLA, A., MARCHI, R., MELLANO, D. \& PONTI, W. (1988) Avian infectious bronchitis: nephropathogenic and respiratory viruses isolated and their spreading in Italy. Proceedings of the International Symposium on Infectious Bronchitis. Giessen, Germany. June 23-26. 1988. pp 245-255

ZANELLA, A. \& MARTINO (1998) Avian infectious bronchitis: persistence of nephropathogenic strains related to serotype AZ23/74. Proceedings of the International Symposium on Infectious Bronchitis and Pneumovirus Infections in Poultry. Giessen, Germany. June 15-18, 1998. pp 189-197

\title{
Novel localised variant of canine epidermolysis bullosa acquisita
}

Veterinary Record (2000) 146, 193-194

T. Olivry, DrVet, $\mathrm{PhD}$, DipACVD, DipECVD, S. M. Dunston, BS, MS, Department of Clinical Sciences, College of Veterinary Medicine, North Carolina State University, Raleigh, North Carolina 27606, USA

A. Petersen, DrMedVet, Department of Small Animal Clinical Sciences, College of Veterinary Medicine, Michigan State University, East Lansing, Michigan, USA M. Chen, PhD, LAC, University of Southern California, Los Angeles, California, USA

\section{T. Olivry, A. Petersen, S. M. Dunston, M. CHEN}

IN 1957, Brunsting and Perry described seven human patients with a chronically recurring blistering and scarring dermatosis preferentially localised to the head and neck (Brunsting and Perry 1957). These authors concluded that their patients were afflicted with a benign subset of bullous pemphigoid (BP) because of the observation of microscopic subepidermal vesicles (Brunsting and Perry 1957). This localised subset of BP was subsequently referred to as 'Brunsting-Perry cicatricial pemphigoid' (CP). In the past two decades, human beings with a clinical phenotype suggestive of Brunsting-Perry $\mathrm{CP}$ have been shown to exhibit skin-fixed and circulating immunoglobulin G (IgG) autoantibodies targeting antigens in anchoring fibrils (Dahl 1979, Gammon and others 1984, Kurzals and others 1991, Karpouzis and others 1993). These findings established that Brunsting-Perry CP actually represented a localised variant of epidermolysis bullosa acquisita (EBA). The latter, recognised in human beings and canine species, is an autoimmune blistering dermatosis that most commonly exhibits a generalised phenotype and seems refractory to therapy. EBA is characterised microscopically by neutrophil-rich

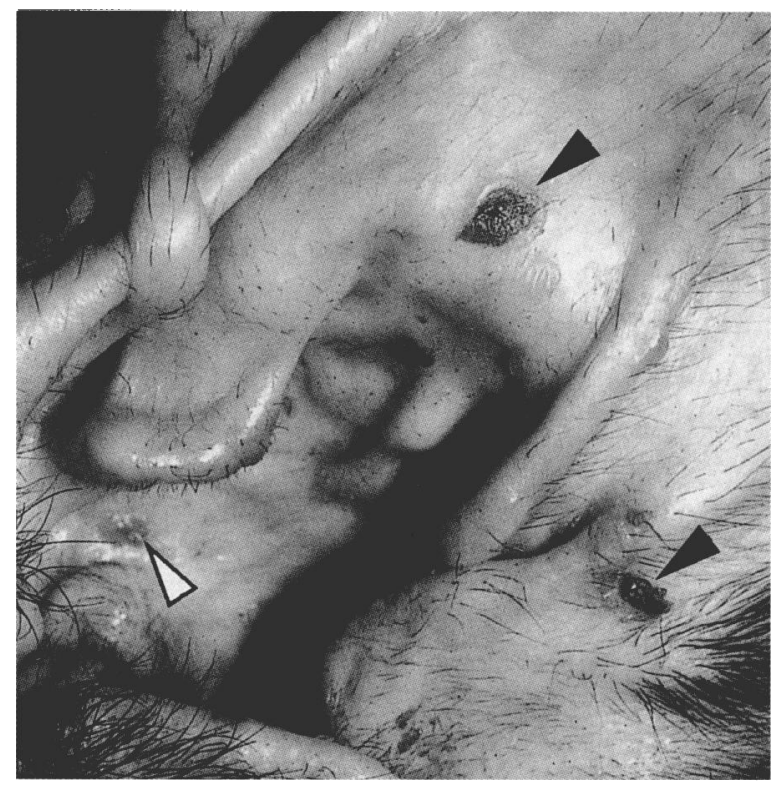

FIG 1: Vesicle (white arrowhead), ulcers and crusts (black arrowheads) present on the concave aspect of the ear pinna

subepidermal vesicles and immunologically by autoantibodies directed against the non-collagenous amino terminus of type VII collagen (Gammon 1991, Olivry and others 1998). The aim of this study was to describe the clinical, histopathological and immunological features of a localised variant of canine EBA which resembled BrunstingPerry $\mathrm{CP}$ in human beings.

An 11-month-old male, intact, German shorthaired pointer was presented with a 12-day history of cutaneous vesicles and ulcers. Initial lesions were scattered on the head and trunk and had rapidly decreased in severity following a short course of corticosteroids at anti-inflammatory doses. At the time of presentation to the dermatologist, vesicles, ulcers and scars were restricted to the concave aspect of the ear pinnae (Fig 1). All active cutaneous lesions progressively resolved with the administration of prednisone at lowimmunosuppressive dosages ( $1 \mathrm{mg} / \mathrm{kg}$ two times a day). The dog was lost to follow-up after the initial remission was achieved.

Histopathological examination of lesional skin biopsy specimens demonstrated that subepidermal cleavage initially occurred with minimal dermal inflammation (Fig 2a). Multiple vesicles, however, were filled with neutrophil granulocytes and appeared as subepidermal microabscesses (Fig $2 \mathrm{~b}$ ). The observed microscopic lesions were indistiguishable from those seen in the skin of dogs with EBA (Olivry and others 1998). Antigen immunomapping, performed with collagen IV-specific monoclonal antibodies (Olivry and others 1998), corroborated that dermoepidermal cleavage occurred below the lamina densa of the epidermal basement membrane.

Direct immunofluorescence testing was performed on frozen skin sections as described by Olivry and others (1998). A very thick deposit of IgG was noticed at the epidermal basement membrane zone in both blistered and non-clefted areas (Fig 3). Basement membrane-fixed immunoglobulin $\mathrm{A}$, immunoglobulin $\mathrm{M}$ and $\mathrm{C} 3$ were not seen. A high titre ( $>1: 500)$ of circulating IgG anti-basement membrane autoantibodies was detected in this dog's serum using normal canine lip as a substrate. When salt-split canine lip epithelium was used (Iwasaki and others 1997, Olivry and others 1998), the IgG autoantibodies were shown to recognise one or more antigen located on the dermal side of artificially clefted skin. These results suggested that 

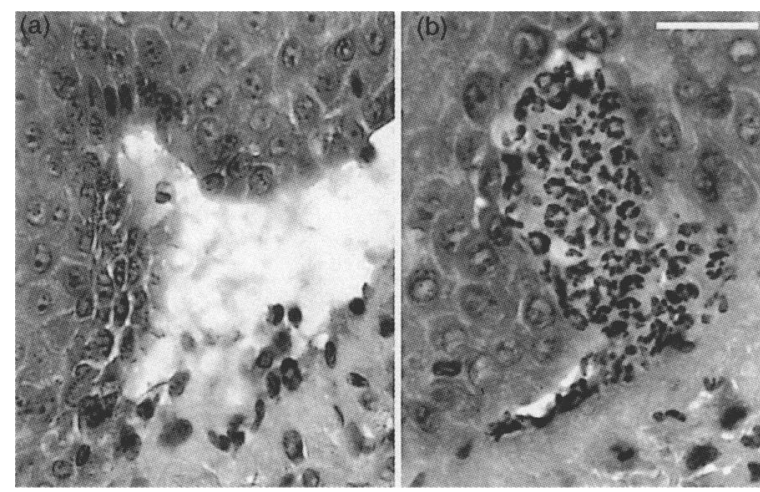

FIG 2: (a) Rare subepidermal vesicles containing few inflammatory cells, (b) while others appear as neutrophil-rich subepidermal microabscesses. Haematoxylin and eosin.

Bar $=100 \mu \mathrm{m}$

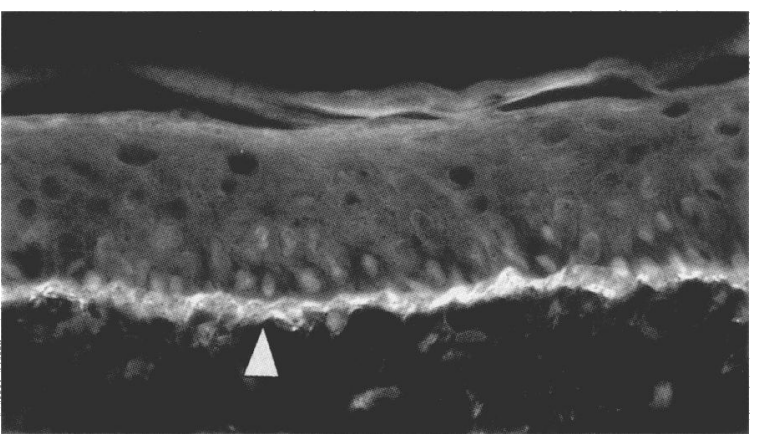

FIG 3: Thick linear and continuous deposit of immunoglubulin G present at the basement membrane zone (arrowhead) $\times 100$

autoantibodies of the dog recognised antigens in or below the lamina densa.

To confirm the target specificity of this dog's serum IgG autoantibodies, an enzyme-linked immunosorbent assay (ELISA) was performed with recombinant human $\mathrm{NCl}$ domain, the non-collagenous amino terminus of type VII collagen. This ELISA had been used as an aid to the diagnosis in human and canine patients affected by EBA and type I bullous systemic lupus erythematosus (BSLE) (Chen and others 1997, Olivry and others 1998, 1999). Moreover, recent cloning of canine $\mathrm{NCl}$ yielded a sequence highly homologous to the human peptide, thereby confirming the validity of using a heterospecific substrate for $\mathrm{NC} 1$ immunoreactivity (Xu and others 1998). The ELISA studies confirmed that this dog's circulating IgG autoantibodies bound human recombinant collagen VII-NC1 with optical densities similar to those of other human and canine patients with EBA or BSLE (Olivry and others 1998, 1999). Conversely, the $\mathrm{NC1}$ recombinant peptide was not recognised by circulating IgG from five normal control dogs. Since immunological investigations confirmed the presence of anti-collagen VII autoimmunity in the dog in this case, the diagnosis of EBA was confirmed (Gammon 1991).

The clinical phenotype exhibited by this dog, predominating to the head region and characterised by vesicles progressing to ulcers and scars, is reminiscent of that of Brunsting-Perry type EBA in human beings (Dahl 1979, Gammon and others 1984, Kurzals and others 1991, Karpouzis and others 1993). Moreover, the lesional distribution observed is remarkably less severe than that seen in other EBA-affected dogs which exhibit generalised and severe blistering and ulcerative lesions (Olivry and others 1998, T. Olivry, unpublished observations). This difference in clinical presentation justifies the recognition of a localised variant of EBA in the canine species.

\section{ACKNOWLEDGEMENTS}

The authors are grateful to Professor R. W. Dunstan for help with the initial histopathological diagnosis.

\section{References}

BRUNSTING, L. A. \& PERRY, H. O. (1957) Benign pemphigoid: a report of seven cases with chronic scarring, herpetiform plaques about the head and neck. Archives of Dermatology 75, 489-501

CHEN, M., CHAN, L. S., CAI, X. Y., O'TOOLE, E. A., SAMPLE, J. C. \& WOODLEY, D. T. (1997) Development of an ELISA for rapid detection of anti-type VII collagen autoantibodies in epidermolysis bullosa acquisita. Journal of Investigative Dermatology 108, 68-72

DAHL, M. G. C. (1979) Epidermolysis bullosa acquisita - a sign of cicatricial pemphigoid. British Journal of Dermatology 101, 475-484

GAMMON, W. R. (1991) Epidermolysis bullosa acquisita: a disease of autoimmunity to type VII collagen. Journal of Autoimmunity 4, 59-71

GAMMON, W. R., BRIGGAMAN, R. A., WOODLEY, D. T., HEALD, P. W. \& WHEELER, C. E. (1984) Epidermolysis bullosa acquisita - a pemphigoid-like disease. Journal of the American Academy of Dermatology 11, 830-832

IWASAKI, T., ISAJI, M., YANAI, T., KITAGAWA, H. \& SASAKI, Y. (1997) Immunomapping of basement membrane zone macromolecules in canine salt-split skin. Journal of Veterinary Medical Science 59, 391-393

KARPOUZIS, A., PROST, C., CORDOLIANI, F., VIGUIER, D., BLUM, L. \& PUISSANT, A. (1993) Acquired localized epidermolysis bullosa. A case with scalp involvement and immunoelectron microscopic study. Annales de Dermatologie et Vénéréologie 120, 464-468

KURZALS, G., STOLZ, W., MEUER, M., KUNZE, J., BRAUN-FALCO, O. \& KRIEG, T. (1991) Acquired epidermolysis bullosa with the clinical features of Brunsting-Perry cicatricial bullous pemphigoid. Archives of Dermatology 127, 391-395

OLIVRY, T., FINE, J-D., DUNSTON, S. M., CHASSE, D., PASCAL TENORIO, A., MONTEIRO-RIVIERE, N. A., CHEN, M. \& WOODLEY, D. T. (1998) Canine epidermolysis bullosa acquisita: circulating autoantibodies target the aminoterminal non-collagenous $(\mathrm{NCl})$ domain of collagen $\mathrm{VII}$ in anchoring fibrils. Veterinary Dermatology 9, 19-31

OLIVRY, T., SAVARY, K. C. M., MURPHY, K. M., DUNSTON, S. M. \& CHEN, M. (1999) Bullous systemic lupus erythematosus (type-1) in a dog. Veterinary Record 145, 165-169

XU, L. T., CHEN, M., PENG, J., O' TOOLE, E. A., WOODLEY, D. T. \& CHAN, L. S. (1998) Molecular cloning and characterization of a CDNA encoding canine type VII collagen non-collagenous $(\mathrm{NC1})$ domain, the target antigen of autoimmune disease epidermolysis bullosa acquisita (EBA). Biochimica et Biophysica Acta - Molecular Basis of Disease 1408, 25-34 